\title{
Meta-analysis of the prevalence of livestock diseases in North Eastern Region of India
}

\author{
Nagendra Nath Barman ${ }^{1}$, Sharanagouda S. Patil ${ }^{2}$, Rashmi Kurli3 ${ }^{3}$ Pankaj Deka ${ }^{1}$, Durlav Prasad Bora ${ }^{1}$, Giti Deka ${ }^{1}$ \\ Kempanahalli M. Ranjitha², Channappagowda Shivaranjini ${ }^{2}$, Parimal Roy ${ }^{4}$ and Kuralayanapalya P. Suresh ${ }^{3}$
}

1. Department of Veterinary Microbiology, College of Veterinary Science, Assam Agriculture University, Guwahati, Assam, India; 2. Department of Virology, ICAR-National Institute of Veterinary Epidemiology and Disease Informatics, Bengaluru, Karnataka, India; 3. Department of Spatial Epidemiology, ICAR-National Institute of Veterinary Epidemiology and Disease Informatics, Bengaluru, Karnataka, India; 4. Director, ICAR-National Institute of Veterinary Epidemiology and Disease Informatics, Bengaluru, Karnataka, India.

Corresponding author: Kuralayanapalya P. Suresh, e-mail: sureshkp97@gmail.com

Co-authors: NNB: nnbarman@gmail.com, SSP: ss.patil@icar.gov.in, RK: rashmikurli@yahoo.in,

PD: drpankajaau@gmail.com, DPB: drdpbora@gmail.com, GD: gitideka8906@gmail.com, KMR: ranjuckm10@gmail.com, CS: shivaranjinicveena@gmail.com, PR: director.nivedi@icar.gov.in

Received: 26-07-2019, Accepted: 22-11-2019, Published online: 11-01-2020

doi: www.doi.org/10.14202/vetworld.2020.80-91 How to cite this article: Barman NN, Patil SS, Kurli R, Deka P, Bora DP, Deka G, Ranjitha KM, Shivaranjini C, Roy P, Suresh KP (2020) Meta-analysis of the prevalence of livestock diseases in North Eastern region of India, Veterinary World, 13(1): 80-91.

\begin{abstract}
Aim: The study aimed to determine the overall prevalence of livestock diseases in North Eastern Region (NER) of India, through a systematic review and meta-analysis of published data.

Materials and Methods: The articles used for the study were retrieved from PubMed, J-Gate Plus, Indian Journals, and Google scholar, R open-source scripting software 3.4.3. Metafor, Meta. The Chi-square test was conducted to assess for the heterogeneity, forest plot (confidence interval [CI] plot) is a method utilized to present the results of meta-analysis, displaying effect estimate and their CIs for each study were used for searching and retrieval of livestock diseases prevalence data in India using a search strategy combining keywords and related database-specific subject terms from 2008 to 2017 in English only.

Results: The prevalence of various livestock diseases are foot-and-mouth disease (21\%), bluetongue (28\%), brucellosis in bovine $(17 \%)$, brucellosis in caprine $(2 \%)$, brucellosis in porcine $(18 \%)$, brucellosis in sheep and goat $(3 \%)$, babesiosis $(6 \%)$, theileriosis $(26 \%)$, porcine reproductive and respiratory syndrome $(1 \%)$, porcine cysticercosis $(6 \%)$, classical swine fever (31\%), Porcine circovirus (43\%), and Peste des petits ruminants (15\%). This information helps policymakers to take appropriate measures to reduce the disease burden.
\end{abstract}

Conclusion: This study indicates that the overall prevalence of various livestock diseases in NER of India.

Keywords: babesiosis, brucellosis, classical swine fever, foot-and-mouth disease, forest plot, livestock, meta-analysis, North Eastern regions, Peste des petits ruminants, Porcine circovirus, porcine cysticercosis, porcine reproductive and respiratory syndrome, prevalence, seroprevalence, theileriosis.

\section{Introduction}

The term "livestock" is nebulous and livestock refers to any breed or population of animals kept by humans for a useful, commercial purpose. India is the world's highest livestock owner at about 512.05 million [1]. Livestock plays an important role in the Indian economy. About 20.5 million people depend on livestock for their livelihood. Livestock contributed $16 \%$ to the income of small farm households as against an average of $14 \%$ for all rural households. Livestock provides a livelihood to two-third of the rural community. It also provides employment to about $8.8 \%$ of the population in India. India has vast livestock resources. The livestock sector contributes $0.15 \%$ point to the

Copyright: Barman, et al. Open Access. This article is distributed under the terms of the Creative Commons Attribution 4.0 International License (http://creativecommons.org/licenses/ by/4.0/), which permits unrestricted use, distribution, and reproduction in any medium, provided you give appropriate credit to the original author(s) and the source, provide a link to the Creative Commons license, and indicate if changes were made. The Creative Commons Public Domain Dedication waiver (http:// creativecommons.org/publicdomain/zero/1.0/) applies to the data made available in this article, unless otherwise stated. gross domestic product (GDP) growth and the share of livestock to the GDP was recorded at $4.29 \%$ and $25.6 \%$ of total agriculture GDP [2].

The North Eastern Region (NER) of India comprising the states of Assam, Arunachal Pradesh, Manipur, Meghalaya, Mizoram, Nagaland, Sikkim, and Tripura occupies about $7 \%$ of total land area and $4 \%$ of the total population of the country. Agriculture is the prime source of livelihood for the majority $(85 \%)$ of the rural population in the NER of India, the consumption of meat is relatively higher in this region, and that of milk and milk products is lower. Coupled with the traditional meat-eating habit, increasing per capita income, urbanization, and changes in lifestyle, the region is deficit in the production of livestock products. Some states in the region depend on inter-state trade in livestock to meet the domestic demand [3]. Livestock disease affects the economy, animal welfare, the environment, and public health. Animals are susceptible to a number of diseases and conditions that may affect their health. Some of the important livestock diseases in NER are foot-and-mouth disease, bluetongue, brucellosis in 
bovine, porcine, sheep and goat, babesiosis, theileriosis, porcine reproductive and respiratory syndrome (PRRS), porcine cysticercosis, classical swine fever (CSF), Porcine circovirus (PCV), and Peste des petits ruminants (PPR). Where the disease condition is serious, governments impose regulations on import and export, on the movement of stock, quarantine restrictions, and the reporting of suspected cases. Vaccines are available against certain viral diseases of livestock and antibiotics are rampantly used against bacterial diseases which require regular surveillance [4]. However, the growth of the livestock sector has been slower in NER than at the national level which needs to be improved. Metaanalysis is a quantitative, formal, and epidemiological study design used to systematically assess the previous research studies to derive conclusions about that body of research. Outcomes from a meta-analysis may include a more precise estimate of the effect of treatment or risk factor for disease, or other outcomes, than any individual study contributing to the pooled analysis [5]. In recent past years, the prevalence of brucellosis, CSF, bovine tuberculosis, and bovine viral diarrhea virus was reported by different researchers in different countries in the world [7,6-22]. However, the prevalence of livestock diseases in the NER of India has not been studied systematically, and therefore, the prevalence status of the diseases is largely unknown at the country level.

This study aimed to systematically review the existing literature and provides a standard estimate of the prevalence of various livestock diseases in NER in India. This would pave the way for epidemiological modeling, which would help to formulate and evaluate control strategies in the distant future.

\section{Materials and Methods}

\section{Ethical approval}

Ethical approval was not required for this study.

\section{Study strategy}

Literatures were collected from the period 2008 to 2017 using various search engines such as PubMed, J-Gate Plus, Indian Journals, and Google scholar. The search was made using the terms such as babesiosis, theileriosis, foot-and-mouth disease, brucellosis, PRRS, porcine cysticercosis, PCV, PPR, and CSF in North East Region. Manual searches on citations retrieved from original studies and review articles were performed. The search was restricted only to studies published in English language or any Indian Languages.

\section{Study selection}

All the search results were limited to cross-sectional, observational, non-randomized, case-control studies, etc., conducted on the animal population. The studies have to meet the following criteria for inclusion, (i) they have to report the number of positive samples for the particular livestock diseases, (ii) number of animals that have been tested, (iii) year of surveillance or year of study conducted, and (iv) studies with standard confirmatory test were included. Studies were excluded if the number of positive samples was not reported either in frequency or proportion, studies such as review articles were also excluded from the study.

\section{Data extraction}

Full articles were collected and examined; two independent reviewers extracted the attributes or characteristics of each included study in a pre-defined data extraction format. This included year of publication, first author, state, total number of samples/sample size, total positive samples for the livestock diseases, and method used for confirmation of it. Any discrepancy in data extraction was resolved through discussion and consensus.

\section{Analytical approach}

The meta-analysis of the prevalence of livestock diseases in the North East Region of India was conducted using the $\mathrm{R}$ open-source scripting software 3.4.3. The $\mathrm{R}$ packages used for meta-analysis were Metafor and Meta. A total of 21 studies were included from various regions of the country.

The Chi-square test was conducted to assess for heterogeneity. It was evaluated using tau $\left(\tau^{2}\right)$ value and its level of significance [23]. Results on meta-analysis for the random effect model were used if the heterogeneity between the studies was found to be significant and higher $\tau^{2}$. $I^{2}$ statistic, a measure of heterogeneity, indicates the percentage of variance between different studies. If the $\mathrm{I}^{2}$ statistic indicates considerable heterogeneity, we combine the summary measures across the studies using a random effect model that assumed that the included study represents a sample from a larger population.

\section{Strategy adopted for addressing heterogeneity}

Numbers of options were used in the present study to address heterogeneity.

1. Check again that data are correct: Errors in unit of analysis, proportion, or prevalence present study may lead to severe heterogeneity because of incorrect extraction

2. Explore heterogeneity: It is our interest to determine the cause of heterogeneity if present among the different studies. We have explored for the presence of heterogeneity by conducting subgroup analysis

3. Performing a random effects model: Fixed effect meta-analysis ignores heterogeneity. Pooled effect estimate from a fixed effect meta-analysis is normally interpreted as being best estimate or prevalence. However, the presence of heterogeneity suggests that there may not be a signal population estimate but a distribution of the number of population effects. Thus, using fixed effect model may be erroneous and random effect model is used to incorporate heterogeneity among the studies

4. Exclude studies: If there is a presence of one or two outline studies (Large tau ${ }^{2}$, we have performed exclusion of these studies from the analysis as they introduce unreliable and bias in the results. 


\section{Forest plot}

Forest plot (confidence interval $[\mathrm{CI}]$ plot) is a method utilized to present the results of meta-analysis, displaying effect estimate and their CIs for each study. Each study is represented by a square at a point estimate of effect and a horizontal line extending either side of the block depicts a $95 \%$ CI.

The area of the block is proportional to the weight assigned to that study in the meta-analysis. Forest plots may include the results if the overall effect from a meta-analysis, normally at the bottom of the graph, and often using a diamond to distinguish from the individual studies.

\section{Sensitivity analysis}

Sensitivity analysis is also been used to examine the effects of studies identified as being atypical concerning conduct or result, or being highly influential in the analysis. This sensitivity is mainly used to explore sources of heterogeneity in the body of the research. In the present study, sensitivity analysis has been employed to detect the influential study by each time omitting one of the studies.

\section{Stratified analysis}

Stratified analysis has been frequently used to reduce the heterogeneity. This approach will reduce but not eliminate heterogeneity. In the present study, stratification is applied for grouping different type of samples such as clinical samples and samples from a healthy animal.

\section{Assessment of heterogeneity}

The heterogeneity was assessed in the present study by conducting meta-analysis. The presence of heterogeneity was indicated by the value of $\tau^{2}$ and significance is assessed by $\mathrm{p}$-value by Chi-square test.

\section{Results}

\section{Prevalence of babesiosis}

The pooled prevalence rate of babesiosis in 1238 samples from 11 studies was $6 \%(95 \% \mathrm{CI}: 3-12 \%)$, $\tau^{2}=1.0699 ; \mathrm{p}<0.01^{* *}$ (Figure-1). Although some variations are seen among various studies, the heterogeneity is significant; hence, the random effect model was chosen [24-34].

\section{Prevalence of bluetongue}

The pooled prevalence rate of bluetongue in 2762 samples from 11 studies was $28 \%(95 \%$ CI: $21-36 \%), \quad \tau^{2}=0.3829 ; \quad \mathrm{p}<0.01 * * \quad$ (Figure-2). Although some variations are seen among various studies, the heterogeneity is significant; hence, the random effect model was chosen [35-44]

\section{Prevalence of foot-and-mouth disease}

The pooled prevalence rate of foot-and-mouth disease in 41,009 samples from 39 studies was 21\% (95\% CI: 18-24\%), $\tau^{2}=0.3681 ; \mathrm{p}=0.00 * *$ (Figure-3). Although some variations are seen among various studies, the heterogeneity is significant; hence, the random effect model was chosen [45-51].

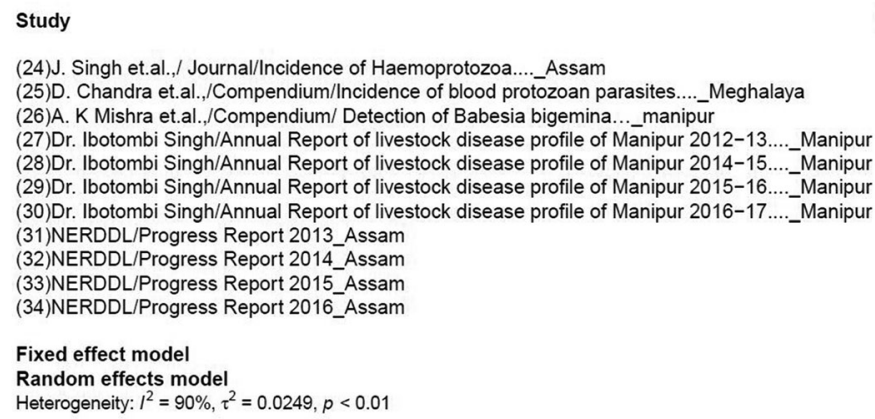

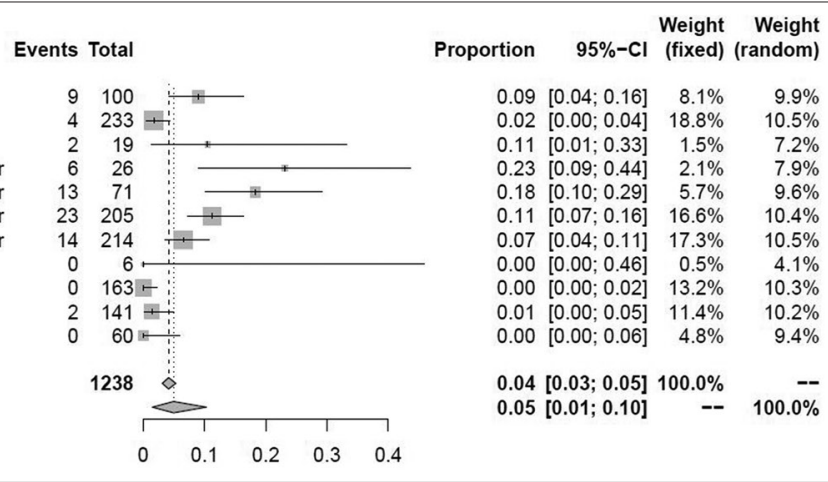

Figure-1: Forest plot of studies on the prevalence of babesiosis.

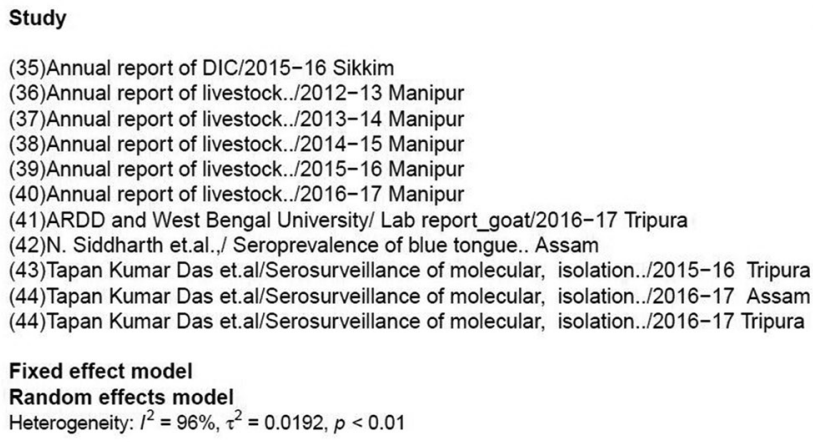

Figure-2: Forest plot of studies on the prevalence of bluetongue.
Weight Weight

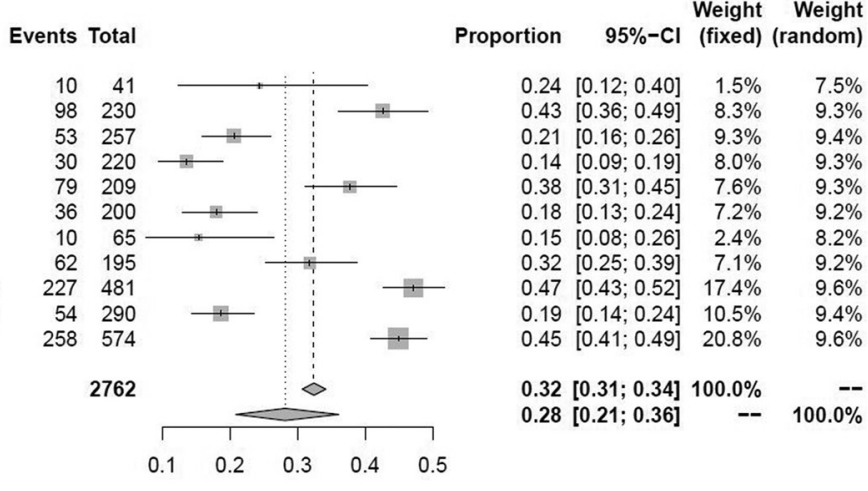




\section{Prevalence of PPR}

The pooled prevalence rate of PPR in 5221 samples from 23 studies was 15\% (95\% CI: 9-25\%), $\tau^{2}=1.6098 ; \mathrm{p}<0.01 * *$ (Figure-4). Although some variations are seen among various studies, the heterogeneity is significant; hence, the random effect model was chosen [30,52-61].

\section{Prevalence of porcine cysticercosis}

The pooled prevalence rate of porcine cysticercosis in 4810 samples from 13 studies was $6 \%$ (95\% CI: 4-9\%), $\tau^{2}=0.7530 ; p<0.01 * *$ (Figure-5). Although some variations are seen among various studies, the heterogeneity is significant; hence, the random effect model was chosen [62-73].

\section{Prevalence of theileriosis}

The pooled prevalence rate of theileriosis in 1468 samples from eight studies was 26\% (95\% CI: $21-32 \%), \quad \tau^{2}=0.1140 ; \quad \mathrm{p}<0.01 * * \quad$ (Figure-6). Although some variations are seen among various studies, the heterogeneity is significant; hence, the random effect model was chosen [25,74-80].

\section{Prevalence of PRRS}

The pooled prevalence rate of PRRS in 91,904 samples from 41 studies was 1\% (95\%
CI: $0-2 \%$ ), $\tau^{2}=3.5224 ; \mathrm{p}<0.01 * *$ (Figure-7). Although some variations are seen among various studies, the heterogeneity is significant; hence, the random effect model was chosen $[60,73,81-94]$.

\section{Prevalence of brucellosis in bovines}

The pooled prevalence rate of bovine brucellosis in 54,056 samples from 14 studies was $17 \%$ (95\% CI: 8-29\%), $\tau^{2}=0.0654 ; \mathrm{p}<0.01 * *$ (Figure-8). Although some variations are seen among various studies, the heterogeneity is significant; hence, the random effect model was chosen [27-30,95-104].

\section{Prevalence of brucellosis in caprine}

The pooled prevalence rate of caprine brucellosis in 1164 samples from two studies was 2\% (95\% CI: $2-4 \%), \tau^{2}=0 ; p=0.44$ (Figure-9). Although some variations are seen among various studies, the heterogeneity is significant; hence, the random effect model was chosen $[101,104]$.

\section{Prevalence of brucellosis in porcine}

The pooled prevalence rate of porcine brucellosis in 448 samples from two studies was 33\% $(95 \%$ CI: $0-99 \%$ ), $\tau^{2}=13.36 ; \mathrm{p}<0.01 * *$ (Figure-10). Although some variations are seen among various studies, the heterogeneity is significant; hence, the random effect model was chosen $[101,105]$.

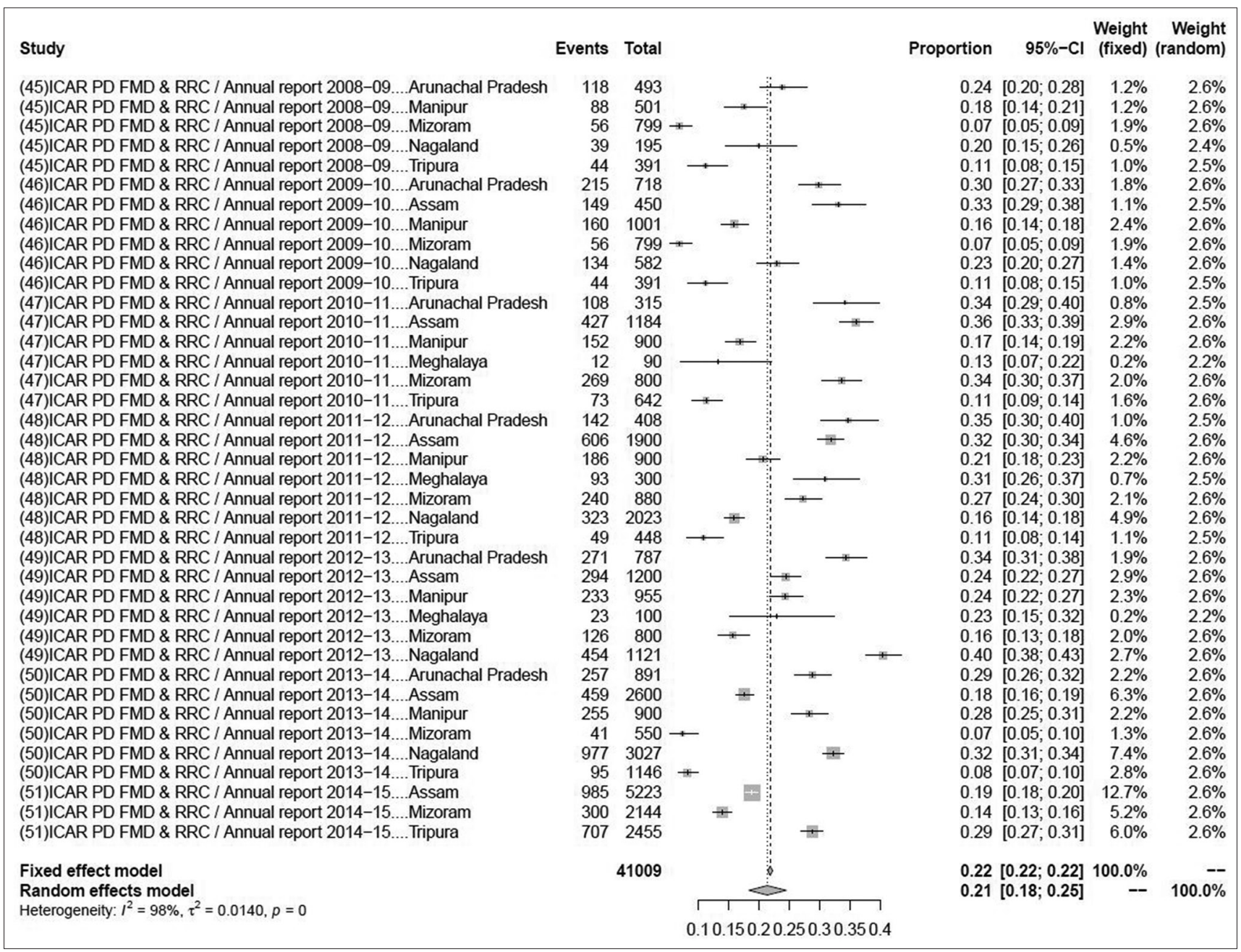

Figure-3: Forest plot of studies on the prevalence of foot-and-mouth disease. 


\begin{tabular}{|c|c|c|c|c|c|c|c|c|c|c|}
\hline Study & Events & Total & & & & & Proportion & $95 \%-\mathrm{Cl}$ & $\begin{array}{l}\text { Weight } \\
\text { (fixed) }\end{array}$ & $\begin{array}{r}\text { Weight } \\
\text { (random) }\end{array}$ \\
\hline (30)Annual report of DIC/2013-14_Sikkim & 10 & 80 & 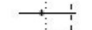 & & & & 0.12 & {$[0.06 ; 0.22]$} & $1.5 \%$ & $4.5 \%$ \\
\hline (52)Progress report NERDDL/2010̄-2017_Assam & 155 & 864 & $\mp$ & & & & 0.18 & {$[0.15 ; 0.21]$} & $16.5 \%$ & $4.7 \%$ \\
\hline (52)Progress report NERDDL/2010-2017_Sikkim & 11 & 43 & & & & & 0.26 & {$[0.14 ; 0.41]$} & $0.8 \%$ & $4.4 \%$ \\
\hline (52)Progress report NERDDL/2010-2017_Arunachal Pradesh & 17 & 46 & & & & & 0.37 & {$[0.23 ; 0.52]$} & $0.9 \%$ & $4.4 \%$ \\
\hline (53)Annual report of livestock disease profile.../2016-17_Manipur & 0 & $200+$ & & & & & 0.00 & {$[0.00 ; 0.02]$} & $3.8 \%$ & $4.6 \%$ \\
\hline (54)V. Balamurgan et.al.,/Prevalence of peste des petits..._Arunachal Pradesh & 5 & 32 & & & & & 0.16 & {$[0.05 ; 0.33]$} & $0.6 \%$ & $4.3 \%$ \\
\hline (54)V. Balamurgan et.al.,/Prevalence of peste des petits...__Assam & 19 & 105 & & & & & 0.18 & {$[0.11 ; 0.27]$} & $2.0 \%$ & $4.6 \%$ \\
\hline (54)V. Balamurgan et.al.,/Prevalence of peste des petits..._.Meghalaya & 2 & 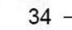 & & & & & 0.06 & {$[0.01 ; 0.20]$} & $0.7 \%$ & $4.3 \%$ \\
\hline (54)V. Balamurgan et.al.,/Prevalence of peste des petits...__Mizoram & 0 & 12 & & & & & 0.00 & {$[0.00 ; 0.26]$} & $0.2 \%$ & $3.7 \%$ \\
\hline (54)V. Balamurgan et.al.,/Prevalence of peste des petits...._Nagaland & 0 & 25 & & & & & 0.00 & {$[0.00 ; 0.14]$} & $0.5 \%$ & $4.2 \%$ \\
\hline (54)V. Balamurgan et.al.,/Prevalence of peste des petits...._Tripura & 11 & 18 & & & & & 0.61 & {$[0.36 ; 0.83]$} & $0.3 \%$ & $4.0 \%$ \\
\hline (54)V. Balamurugan et al.,/ Prevalence of peste des petits.._Manipur & 0 & 92 & & & & & 0.00 & {$[0.00 ; 0.04]$} & $1.8 \%$ & $4.5 \%$ \\
\hline (54)V. Balamurugan et al.,/ Prevalence of peste des petits.._Nagaland & 0 & 25 & & & & & 0.00 & {$[0.00 ; 0.14]$} & $0.5 \%$ & $4.2 \%$ \\
\hline (54)V. Balamurugan et al.,/ Prevalence of peste des petits.._Arunachal Pradesh & 5 & 32 & & & & & 0.16 & {$[0.05 ; 0.33]$} & $0.6 \%$ & $4.3 \%$ \\
\hline (54)V. Balamurugan et al.,/ Prevalence of peste des petits..-Tripura & 11 & 18 & & & & & 0.61 & {$[0.36 ; 0.83]$} & $0.3 \%$ & $4.0 \%$ \\
\hline (54)V. Balamurugan et al.,/ Prevalence of peste des petits.._Mizoram & 0 & 12 & & & & & 0.00 & {$[0.00 ; 0.26]$} & $0.2 \%$ & $3.7 \%$ \\
\hline (55)Maitrayee Devi et.al.,/Seroprevalence and moleular detection...._Assam & 579 & 1831 & & + & & & 0.32 & {$[0.29 ; 0.34]$} & $35.1 \%$ & $4.7 \%$ \\
\hline (56)Safeeda Sultana Begum et.al.,/Seroprevalence of Peste Des Petits..._Assam & 121 & 918 & 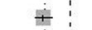 & & & & 0.13 & {$[0.11 ; 0.16]$} & $17.6 \%$ & $4.7 \%$ \\
\hline (57)Active Surveillance data under ADMaC.../2015_Meghalaya & 2 & $38-$ & & & & & 0.05 & {$[0.01 ; 0.18]$} & $0.7 \%$ & $4.3 \%$ \\
\hline (58)Dr. Muzaharrul Islam / Prevalence, pathology and molecular studies...._Assam & 209 & 456 & & $\rightarrow$ & & & 0.46 & {$[0.41 ; 0.51]$} & $8.7 \%$ & $4.7 \%$ \\
\hline (59)Lab Report/AH \& Vety Dept and Dairy Development_Arunachal Pradesh & 4 & 50 & & & & & 0.08 & {$[0.02 ; 0.19]$} & $1.0 \%$ & $4.4 \%$ \\
\hline (60)Active Surveillance Data.../2016_Meghalaya & 18 & 270 & + & & & & 0.07 & {$[0.04 ; 0.10]$} & $5.2 \%$ & $4.6 \%$ \\
\hline (61)Active Surveillance Data..../2017_July-Dec_Meghalaya & 13 & 20 & & & & & 0.65 & {$[0.41 ; 0.85]$} & $0.4 \%$ & $4.1 \%$ \\
\hline Fixed effect model & & 5221 & 0 & & & & 0.21 & {$[0.19 ; 0.22]$} & $100.0 \%$ & \\
\hline & & & $<$ & & & & 0.14 & {$[0.07 ; 0.23]$} & -- & $100.0 \%$ \\
\hline \multirow[t]{2}{*}{ Heterogeneity: $I^{2}=97 \%, \tau^{2}=0.0803, p<0.01$} & & & 1 & $T$ & 1 & 1 & & & & \\
\hline & & 0 & 0.2 & 0.4 & 0.6 & 0.8 & & & & \\
\hline
\end{tabular}

Figure-4: Forest plot of studies on the prevalence of Peste des Petits Ruminants.

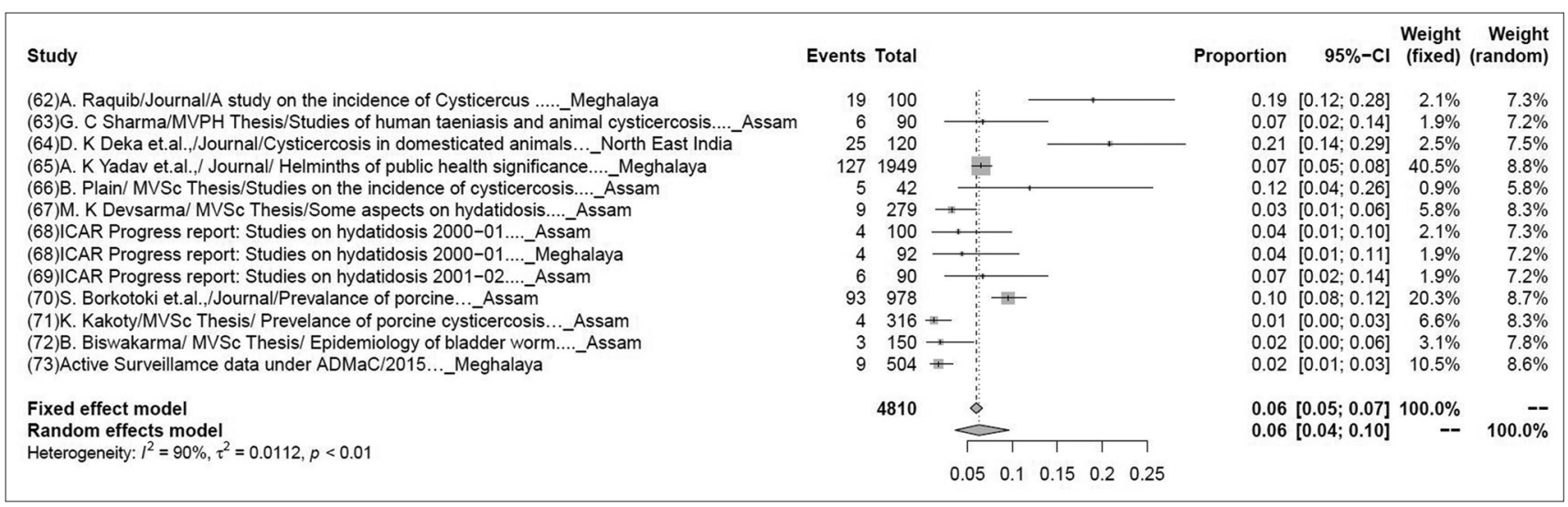

Figure-5: Forest plot of studies on the prevalence of porcine cysticercosis.

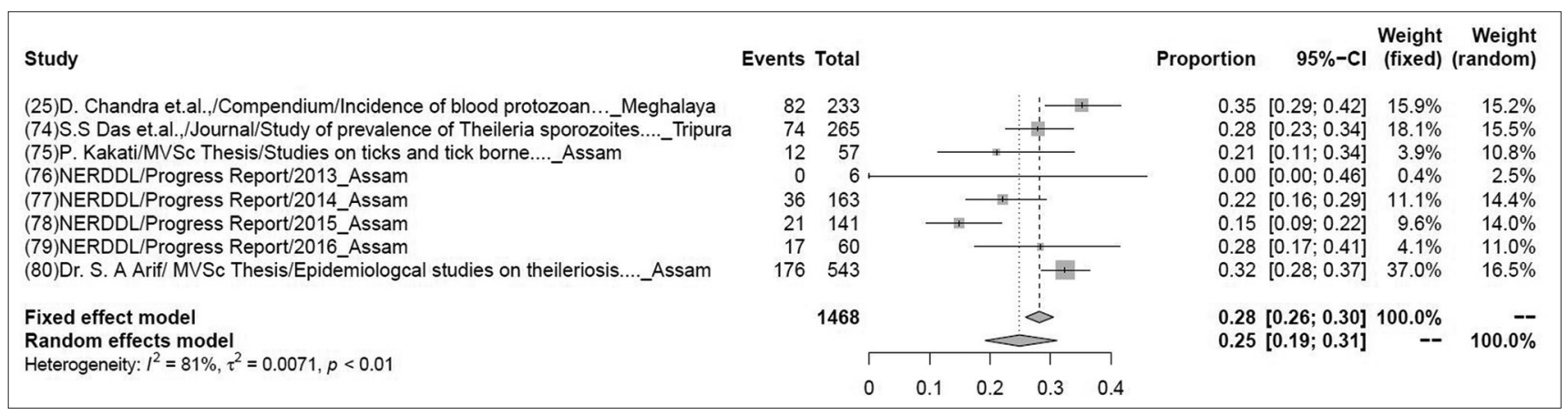

Figure-6: Forest plot of studies on the prevalence of theileriosis.

\section{Prevalence of brucellosis in sheep and goat}

The pooled prevalence rate of sheep and goat brucellosis in 1129 samples from four studies was 3\% (95\% CI: $2-4 \%), \tau^{2}=0 ; p=0.59$ (Figure-11). Although some variations are seen among various studies, the heterogeneity is significant; hence, the random effect model was chosen [28-30,99].

\section{Prevalence of PCV}

The pooled prevalence of PCV in 2802 samples from 38 studies was $43 \%$ (95\% CI: $2-4 \%$ ), $\tau^{2}=4.253$; $\mathrm{p}<0.01 * *$ (Figure-12). Although some variations are seen among various studies, the heterogeneity is significant; hence, the random effect model was chosen [106-109]. 


\begin{tabular}{|c|c|c|c|c|c|c|c|c|c|c|}
\hline Study & Events & Total & & & & & Proportion & $95 \%-\mathrm{Cl}$ & $\begin{array}{l}\text { Weight } \\
\text { I (fixed) }\end{array}$ & $\begin{array}{l}\text { Weight } \\
\text { (random) }\end{array}$ \\
\hline (60)Animal Resource Development Department, Tripura and ICAR-Barapani/Lab Report_Tripura & 0 & 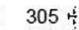 & & & & & 0.00 & {$[0.00 ; 0.01]$} & $0.3 \%$ & $2.5 \%$ \\
\hline (73)State Disease Diagnostic Lab Monthly Progress Report 2013_Meghalaya & 24 & 941 & + & & & & 0.03 & {$[0.02 ; 0.04]$} & $1.0 \%$ & $2.6 \%$ \\
\hline (73)State Disease Diagnostic Lab Monthly Progress Report 2014_Meghalaya & 40 & 1344 & + & & & & 0.03 & {$[0.02 ; 0.04]$} & $1.5 \%$ & $2.6 \%$ \\
\hline (73)State Disease Diagnostic Lab Monthly Progress Report 2015_Meghalaya & 14 & 878 & & & & & 0.02 & {$[0.01 ; 0.03]$} & $1.0 \%$ & $2.6 \%$ \\
\hline (81)Lab maintianed data_Assam & 0 & $320 \stackrel{4}{i}$ & & & & & 0.00 & {$[0.00 ; 0.01]$} & $0.3 \%$ & $2.5 \%$ \\
\hline (82)Progress report NEREDL_Assam & & 21747 & & & & & 0.00 & {$[0.00 ; 0.00]$} & $23.7 \%$ & $2.6 \%$ \\
\hline (83)Annual report 2012-13/DIL AH \& Vety Dept_Manipur & 0 & 167 & & & & & 0.00 & {$[0.00 ; 0.02]$} & $0.2 \%$ & $2.4 \%$ \\
\hline (84)Annual report 2016-17/DIL AH \& Vety Dept_Manipur & 0 & 314 & & & & & 0.00 & {$[0.00 ; 0.01]$} & $0.3 \%$ & $2.5 \%$ \\
\hline (85)AH \& Vety Dept/2012-13_Manipur & 0 & 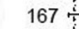 & & & & & 0.00 & {$[0.00 ; 0.02]$} & $0.2 \%$ & $2.4 \%$ \\
\hline (86)AH \& Vety Dept/2016-17_Manipur & 0 & $314 \stackrel{b}{t}$ & & & & & 0.00 & {$[0.00 ; 0.01]$} & $0.3 \%$ & $2.5 \%$ \\
\hline (87)2015/Active Surveillance data under ADMaC _.._Meghalaya & 21 & 975 & :- & & & & 0.02 & {$[0.01 ; 0.03]$} & $1.1 \%$ & $2.6 \%$ \\
\hline (88)2016/Active Surveillance data under ADMaC_.._-Meghalaya & 219 & 2621 & + & & & & 0.08 & {$[0.07 ; 0.09]$} & $2.9 \%$ & $2.6 \%$ \\
\hline (89)2016/Active Surveillance data under ADMaC..._Nagaland & 2 & $190+$ & & & & & 0.01 & {$[0.00 ; 0.04]$} & $0.2 \%$ & $2.4 \%$ \\
\hline (89)2016/Active Surveillance data under ADMaC..._Manipur & 0 & 154 & & & & & 0.00 & {$[0.00 ; 0.02]$} & $0.2 \%$ & $2.4 \%$ \\
\hline (89)2016/Active Surveillance data under ADMaC..._Assam & 0 & 25 & & & & & 0.00 & {$[0.00 ; 0.14]$} & $0.0 \%$ & $1.7 \%$ \\
\hline (89)2016/Active Surveillance data under ADMaC ..._Tripura & 0 & 305 䉂 & & & & & 0.00 & {$[0.00 ; 0.01]$} & $0.3 \%$ & $2.5 \%$ \\
\hline (89)2016/Active Surveillance data under ADMaC..._Mizoram & 35 & 232 & & + & & & 0.15 & {$[0.11 ; 0.20]$} & $0.3 \%$ & $2.5 \%$ \\
\hline (90)2017/Active Surveillance data under ADMaC..._Meghalaya & 9 & 249 & & & & & 0.04 & {$[0.02 ; 0.07]$} & $0.3 \%$ & $2.5 \%$ \\
\hline (90)2017/Active Surveillance data under ADMaC..._Assam & 0 & 7 是 & & & & & 0.00 & {$[0.00 ; 0.41]$} & $0.0 \%$ & $0.8 \%$ \\
\hline (90)2017/Active Surveillance data under ADMaC..._Nagaland & 84 & $381 !$ & & $\longrightarrow$ & & & 0.22 & {$[0.18 ; 0.27]$} & $0.4 \%$ & $2.5 \%$ \\
\hline (90)2017/Active Surveillance data under ADMaC..._Manipur & 0 & 154 & & & & & 0.00 & {$[0.00 ; 0.02]$} & $0.2 \%$ & $2.4 \%$ \\
\hline (91)2013-14/ICAR-Barapani data_Assam & 0 & 4192 & & & & & 0.00 & {$[0.00 ; 0.00]$} & $4.6 \%$ & $2.6 \%$ \\
\hline (91)2013-14/ICAR-Barapani data_Arunachal Pradesh & 0 & 400 & & & & & 0.00 & {$[0.00 ; 0.01]$} & $0.4 \%$ & $2.5 \%$ \\
\hline (91)2013-14/ICAR-Barapani data_Mizoram & 263 & 7655 & : & & & & 0.03 & {$[0.03 ; 0.04]$} & $8.3 \%$ & $2.6 \%$ \\
\hline (91)2013-14/ICAR-Barapani data_Meghalaya & 19 & 943 & $i^{+}$ & & & & 0.02 & {$[0.01 ; 0.03]$} & $1.0 \%$ & $2.6 \%$ \\
\hline (91)2013-14/ICAR-Barapani data_Nagaland & 1 & 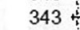 & & & & & 0.00 & {$[0.00 ; 0.02]$} & $0.4 \%$ & $2.5 \%$ \\
\hline (91)2013-14/ICAR-Barapani data_Manipur & 0 & 361 & & & & & 0.00 & {$[0.00 ; 0.01]$} & $0.4 \%$ & $2.5 \%$ \\
\hline (92)2014-15/ICAR-Barapani data_Assam & 8 & 10695 & & & & & 0.00 & {$[0.00 ; 0.00]$} & $11.6 \%$ & $2.6 \%$ \\
\hline (92)2014-15/ICAR-Barapani data_Arunachal Pradesh & 0 & 370 & & & & & 0.00 & {$[0.00 ; 0.01]$} & $0.4 \%$ & $2.5 \%$ \\
\hline (92)2014-15/ICAR-Barapani data_Mizoram & 532 & 7094 & \pm & & & & 0.07 & {$[0.07 ; 0.08]$} & $7.7 \%$ & $2.6 \%$ \\
\hline (92)2014-15/ICAR-Barapani data_Meghalaya & 331 & 2019 & & + & & & 0.16 & {$[0.15 ; 0.18]$} & $2.2 \%$ & $2.6 \%$ \\
\hline (92)2014-15/ICAR-Barapani data_Nagaland & 0 & $320+$ & & & & & 0.00 & {$[0.00 ; 0.01]$} & $0.3 \%$ & $2.5 \%$ \\
\hline (92)2014-15/ICAR-Barapani data_Manipur & 2 & 961 & & & & & 0.00 & {$[0.00 ; 0.01]$} & $1.0 \%$ & $2.6 \%$ \\
\hline (92)2014-15/ICAR-Barapani data_Tripura & 0 & 62 & & & & & 0.00 & {$[0.00 ; 0.06]$} & $0.1 \%$ & $2.1 \%$ \\
\hline (93)2015-17/ICAR-Barapani data_Assam & 0 & 4521 & & & & & 0.00 & {$[0.00 ; 0.00]$} & $4.9 \%$ & $2.6 \%$ \\
\hline (93)2015-17/ICAR-Barapani data_Mizoram & 285 & 4106 & * & & & & 0.07 & {$[0.06 ; 0.08]$} & $4.5 \%$ & $2.6 \%$ \\
\hline (93)2015-17/ICAR-Barapani data_Meghalaya & 22 & 951 & ;- & & & & 0.02 & {$[0.01 ; 0.03]$} & $1.0 \%$ & $2.6 \%$ \\
\hline (93)2015-17/ICAR-Barapani data_Nagaland & 2 & 330 & & & & & 0.01 & {$[0.00 ; 0.02]$} & $0.4 \%$ & $2.5 \%$ \\
\hline (93)2015-17/ICAR-Barapani data_Manipur & 0 & 402 & & & & & 0.00 & {$[0.00 ; 0.01]$} & $0.4 \%$ & $2.5 \%$ \\
\hline (93)2015-17/ICAR-Barapani data_Tripura & 0 & 15 & & & & & 0.00 & {$[0.00 ; 0.22]$} & $0.0 \%$ & $1.3 \%$ \\
\hline (94)NERDDL Data/Dept of AH \& Vety.,Assam_Assam & 8 & 14374 & & & & & 0.00 & {$[0.00 ; 0.00]$} & $15.6 \%$ & $2.6 \%$ \\
\hline Fixed effect model & & 91904 & & & & & 0.01 & {$[0.01 ; 0.01]$} & $100.0 \%$ & -- \\
\hline Random effects model & & & $\dot{0}$ & & & & 0.01 & {$[0.00 ; 0.02]$} & -- & $100.0 \%$ \\
\hline \multirow[t]{2}{*}{ Heterogeneity: $I^{2}=99 \%, \tau^{2}=0.0169, p=0$} & & 「 & 1 & 1 & 1 & $\neg$ & & & & \\
\hline & & 0 & 0.1 & 0.2 & 0.3 & 0.4 & & & & \\
\hline
\end{tabular}

Figure-7: Forest plot of studies on the prevalence of porcine reproductive and respiratory syndrome.

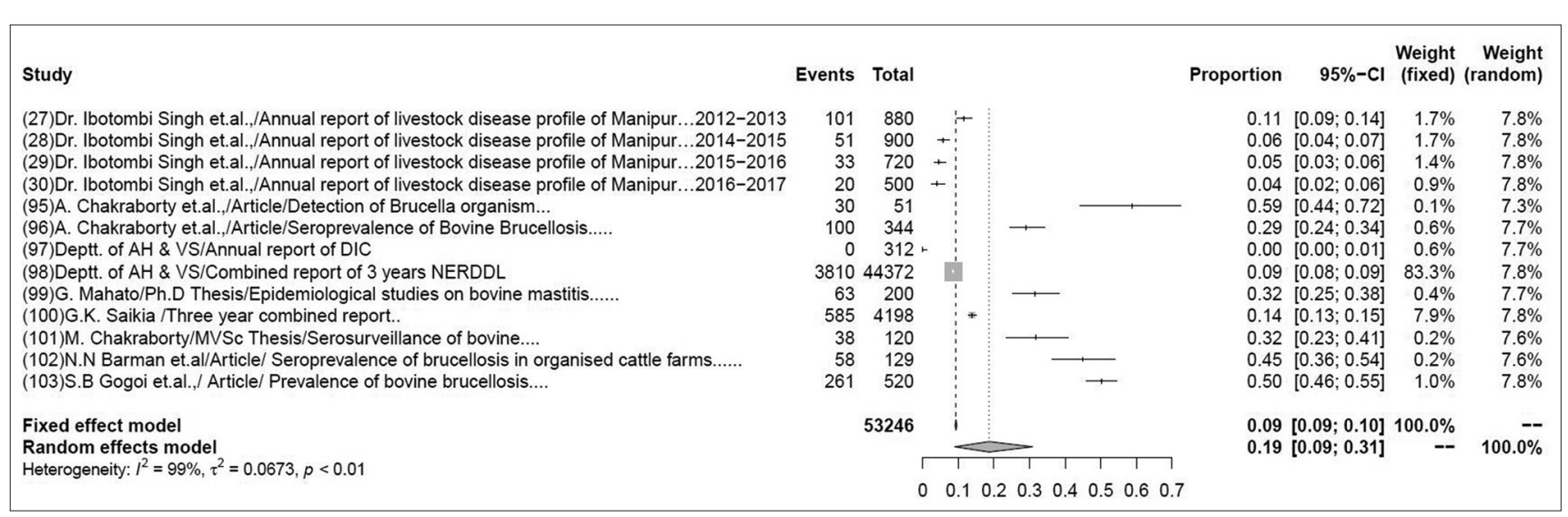

Figure-8: Forest plot of studies on the prevalence of bovine brucellosis.

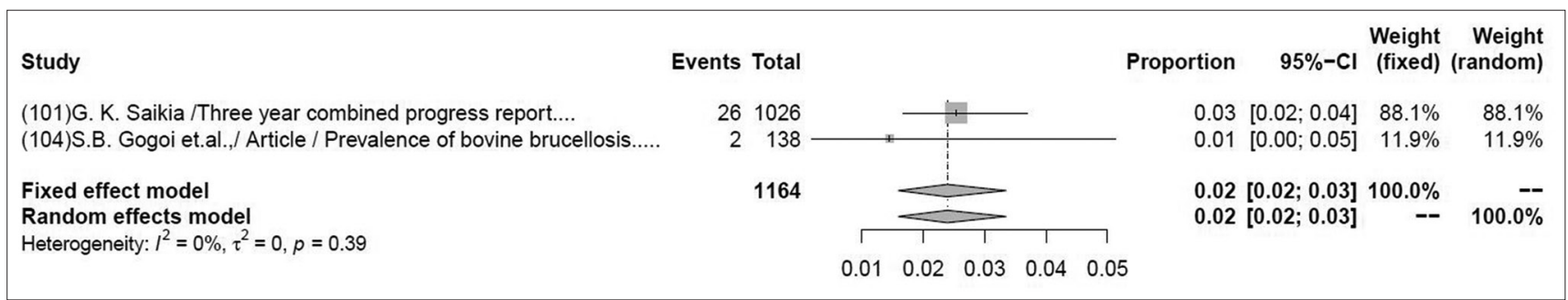

Figure-9: Forest plot of studies on the prevalence of brucellosis in caprine.

\section{Prevalence of CSF}

The pooled prevalence of CSF in 1323 samples from 11 studies was 31\% (95\% CI: $2-4 \%), \tau^{2}=1.088$; $\mathrm{p}<0.01 * *$ (Figure-13). Although some variations are seen among various studies, the heterogeneity is significant; hence, the random effect model was chosen [110-116].

Table-1 provides an insight into the overall meta-analysis summary of 13 livestock diseases. 


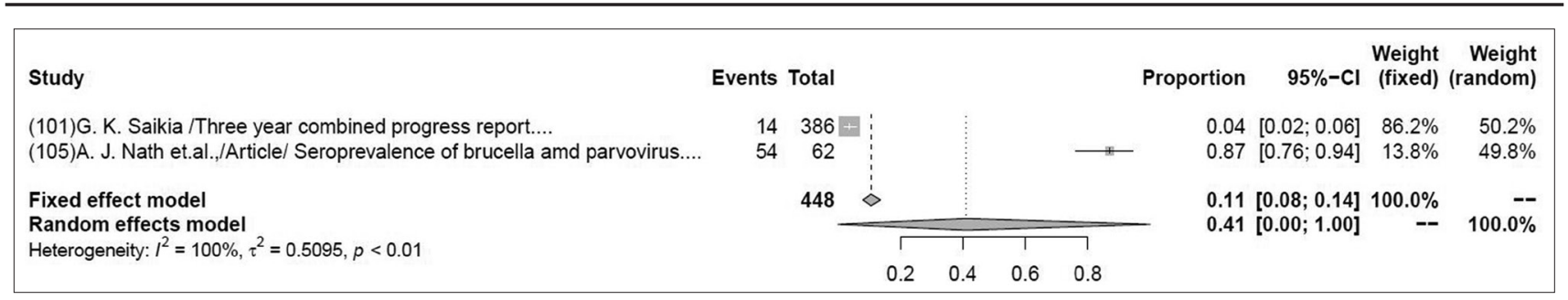

Figure-10: Forest plot of studies on the prevalence of brucellosis in porcine.

\begin{tabular}{|c|c|c|c|c|c|c|}
\hline Study & Events Total & & Proportion & $95 \%-\mathrm{Cl}$ & $\begin{array}{c}\text { Weight } \\
\text { (fixed) }\end{array}$ & $\begin{array}{r}\text { Weight } \\
\text { (random) }\end{array}$ \\
\hline (28)Dr. Ibotombi Singh et.al.,/Annual report of livestock disease profile of Manipur...2014-2015 & 220 & 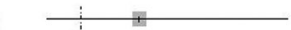 & 0.04 & {$[0.02 ; 0.08]$} & $19.5 \%$ & $19.5 \%$ \\
\hline (29)Dr. Ibotombi Singh et.al.,/Annual report of livestock disease profile of Manipur...2015-2016 & $7 \quad 264$ & $\stackrel{\vdots}{\vdots}$ & 0.03 & {$[0.01 ; 0.05]$} & $23.4 \%$ & $23.4 \%$ \\
\hline (30)Dr. Ibotombi Singh et.al.,/Annual report of livestock disease profile of Manipur...2016-2017 & 5200 & $\underline{1}$ & 0.02 & {$[0.01 ; 0.06]$} & $17.7 \%$ & $17.7 \%$ \\
\hline (99)Dr. Ibotombi Singh et.al.,/Annual report of livestock disease profile of Manipur...2013-2014 & 445 & $\ldots$ & 0.02 & {$[0.01 ; 0.04]$} & $39.4 \%$ & $39.4 \%$ \\
\hline Fixed effect model & 1129 & $\mathrm{i}_{\mathrm{i}}$ & 0.03 & {$[0.02 ; 0.04]$} & $100.0 \%$ & -- \\
\hline Random effects model & & 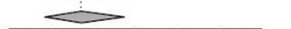 & 0.03 & {$[0.02 ; 0.04]$} & - & $100.0 \%$ \\
\hline \multirow[t]{2}{*}{ Heterogeneity: $I^{2}=0 \%, \tau^{2}=0, p=0.63$} & & 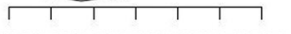 & & & & \\
\hline & & .010 .020 .030 .040 .050 .060 .07 & & & & \\
\hline
\end{tabular}

Figure-11: Forest plot of studies on the prevalence of brucellosis in sheep and goat.

\section{Discussion}

The present study was intended to know the overall prevalence of livestock diseases in NER of India by meta-analyses of reports on the prevalence of the diseases. Large data set is important for projecting country-level prevalence and to identify the severely affected regions and mobilization of resources. Metaanalysis has become the standard for quantitative evidence synthesis, offering a broadly accepted and statistically powerful framework for integrating and adding value to previously published large databases containing raw or partially annotated information. In addition, data mentioned in annual reports of AICRP, annual reports on livestock diseases, State Disease Diagnostic Lab Monthly Progress Report, Progress Report of North East Regional Disease Diagnostic Laboratory, Annual Report of Disease investigation laboratory of NER, Lab maintained data of Directorate of Veterinary and Animal Husbandry Services, and lab reports of Animal Resource Development Department of NER also were taken into account for the calculation of total prevalence.

The present study indicates the pooled prevalence rate of various livestock diseases. As per the present study, the pooled prevalence rate of babesiosis for a sample size of 1238 from 11 studies was $6 \%$ (95\% CI: 3-12\%), and this finding is slightly lower than the previous study, which showed that overall prevalence of babesiosis in cattle was $8.78 \%$ conducted in and around Guwahati, the headquarter of Kamrup (Metropolitan) district, and the capital city of Assam [117]. The pooled prevalence rate of bluetongue in 2762 samples from 11 studies was $28 \%$ (95\% CI: $21-36 \%$ ), as per the earlier studies, overall $43.07 \%$ seroprevalence of bluetongue virus group-specific antibodies was detected in goats and cattle, this was showing higher prevalence rate than the present study [118]. The pooled prevalence rate of foot-and-mouth disease in 41,009 samples from 39 studies was $21 \%$
(95\% CI: 18-24\%), foot-and-mouth disease virus in bovine of Diyala province appeared with the high seroprevalence $(25.33 \%)$ when 114 out of 450 tested animal sera were positive by $3 \mathrm{ABC}$ test to non-structural protein antigens, this was slightly higher than the present study [119]. The pooled prevalence rate of PPR in 5221samples from 23 studies was $15 \%(95 \%$ CI: $9-25 \%$ ), as per the previous study, it indicates the lower prevalence rate (15.79\%) [56]. The pooled prevalence rate of porcine cysticercosis in 4810 samples from 13 studies was $6 \%$ (95\% CI: 4-9\%). The earlier studies indicate that the prevalence rate of porcine cysticercosis was ranged from $5.71 \%$ to $14.06 \%$, it was showing variations because the prevalence rate was determined based on the sex, breed, season, etc. [120]. The pooled prevalence rate of theileriosis in 1468 samples from eight studies was $26 \%(95 \% \mathrm{CI}$ : $21-32 \%)$. This finding is much lower than the previous investigation finding 620 cattle blood samples that were screened using Giemsa's staining technique. The microscopic examination of blood smears revealed $9.35 \%$, overall prevalence of theileriosis. The highest prevalence was found in the summer season with a prevalence rate of $13.3 \%$ which indicates that theileriosis spread more in hot and humid weather (summer season) [121].

The pooled prevalence rate of PRRS in 91,904 samples from 41 studies was $1 \% \quad(95 \%$ CI: $0-2 \%)$. The pooled prevalence rate of caprine brucellosis in 1164 samples from two studies was $2 \%$ (95\% CI: $2-4 \%$ ). The previous reports suggested that the prevalence rate of caprine brucellosis was $2.30 \%$ above 18 months of age, higher than the present study [104]. The pooled prevalence rate of porcine brucellosis in 448 samples from two studies was 33\% (95\% CI: 0-99\%). The pooled prevalence rate of sheep and goat brucellosis in 1129 samples from four studies was 3\% (95\% CI: 2-4\%), which was showing higher prevalence rate than the previous study, it means 


\section{Study}

(106)Uttaran/Ribhoi Megh/2015

(106)Uttaran/Ribhoi Megh/2015

(106)Uttaran/Jaintia Megh/2015

(106)Uttaran/W Kashi Megh/2015

(106)Uttaran/S Garo Megh/2015

(106)Uttaran/E Khasi Megh/2015

(106)Uttaran/W Imphal Manipur/2015

(106)Uttaran/E Imphal Manipur/2015

(106)Uttaran/Thoubal Manipur/2015

(106)Uttaran/Church Manipur/2015

(106)Uttaran/Darrang Assam/2015

(106)Uttaran/Gola Assam/2015

(106)Uttaran/Nagaon Assam/2015

(106)Uttaran/Dhema Assam/2015

(106)Uttaran/Sivas Assam/2015

(106)Uttaran/Sonit Assam/2015

(106)Uttaran/Kola Mizoram/2015

(106)Uttaran/Aiza Mizoram/2015

(106)Uttaran/Kohima NL/2015

(106)Uttaran/Zunhe NL/2015

(106)Uttaran/Ranga NL/2015

(106)Uttaran/Tezu Arunachal/2015

(107)ADMaC Report/Aizawal Mizo/2015

(107)ADMaC Report/Champ Mizo/2015

(107)ADMaC Report/Kolas Mizo/2015

(107)ADMaC Report/Lawng Mizo/2015

(107)ADMaC Report/lung Mizo/2015

(107)ADMaC Report/Mamit Mizo/2015

(107)ADMaC Report/Saiha Mizo/2015

(107)ADMaC Report/Serchp Mizo/2015

(108)DBT TWING/Assam/2012

(108)DBT TWING/Meghalaya/2012

(108)DBT TWING/Mizoram/2012

(108)DBT TWING/Nagaland/2012

(108)DBT TWING/Manipur/2012

(108)DBT TWING/Arunachal/2012

(108)DBT TWING/Tripura/2012

(109)Sharma/Kamrup Assam/2013

\section{Fixed effect model}

Random effects mode

Heterogeneity: $I^{2}=98 \%, \tau^{2}=0.1893, p=0$

\section{Events Total}

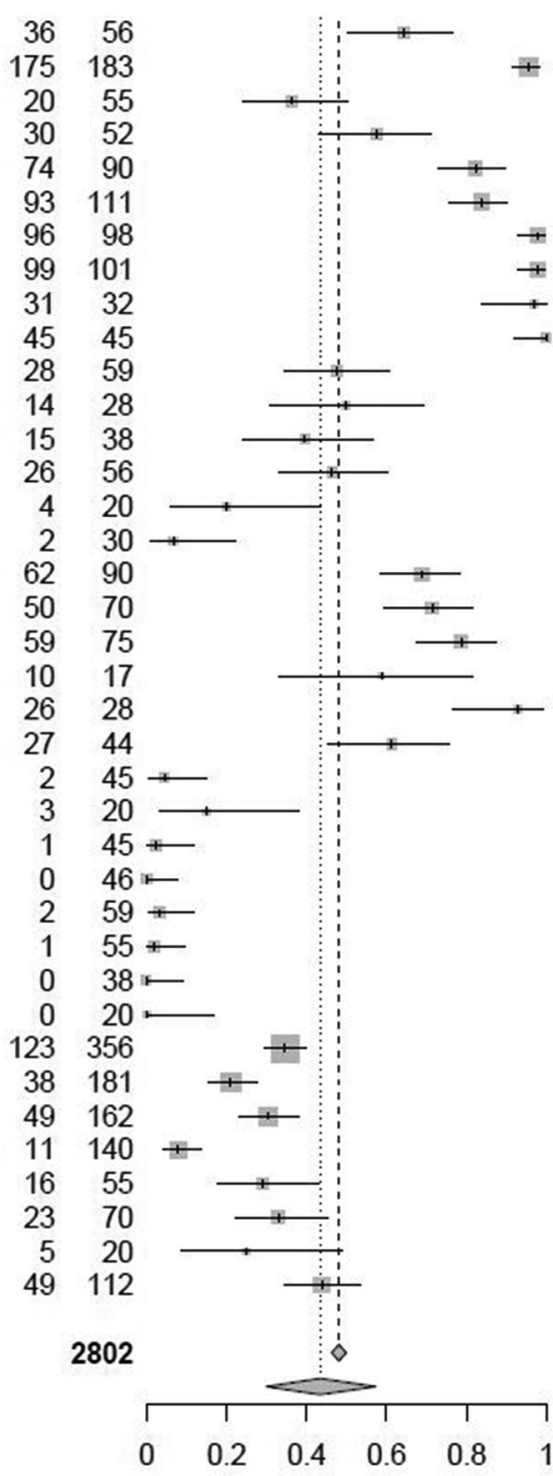

Weight Weight

Proportion $\quad 95 \%-\mathrm{Cl}$ (fixed) (random)

$0.64[0.50 ; 0.77] \quad 2.0 \% \quad 26 \%$

$0.96[0.92 ; 0.98] \quad 6.5 \% \quad 2.7 \%$

$0.36[0.24 ; 0.50] \quad 2.0 \% \quad 2.6 \%$

$0.58[0.43 ; 0.71] \quad 1.9 \% \quad 2.6 \%$

$0.82[0.73 ; 0.89] \quad 3.2 \% \quad 2.7 \%$

$0.84[0.76 ; 0.90] \quad 4.0 \% \quad 2.7 \%$

$0.98[0.93 ; 1.00] \quad 3.5 \% \quad 2.7 \%$

$0.98[0.93 ; 1.00] \quad 3.6 \% \quad 2.7 \%$

$0.97[0.84 ; 1.00] \quad 1.1 \% \quad 2.6 \%$

$1.00[0.92 ; 1.00] \quad 1.6 \% \quad 2.6 \%$

$0.47[0.34 ; 0.61] \quad 2.1 \% \quad 2.6 \%$

$0.50[0.31 ; 0.69] \quad 1.0 \% \quad 2.6 \%$

$0.39[0.24 ; 0.57] \quad 1.4 \% \quad 2.6 \%$

$0.46[0.33 ; 0.60] \quad 2.0 \% \quad 2.6 \%$

$0.20[0.06 ; 0.44] \quad 0.7 \% \quad 2.5 \%$

$0.07[0.01 ; 0.22] \quad 1.1 \% \quad 2.6 \%$

$0.69[0.58 ; 0.78] \quad 3.2 \% \quad 2.7 \%$

$0.71[0.59 ; 0.82] \quad 2.5 \% \quad 2.7 \%$

$0.79[0.68 ; 0.87] \quad 2.7 \% \quad 2.7 \%$

$0.59[0.33 ; 0.82] \quad 0.6 \% \quad 2.5 \%$

$0.93[0.76 ; 0.99] \quad 1.0 \% \quad 2.6 \%$

$0.61[0.45 ; 0.76] \quad 1.6 \% \quad 2.6 \%$

$0.04[0.01 ; 0.15] \quad 1.6 \% \quad 2.6 \%$

$0.15[0.03 ; 0.38] \quad 0.7 \% \quad 2.5 \%$

$0.02[0.00 ; 0.12] \quad 1.6 \% \quad 2.6 \%$

$0.00[0.00 ; 0.08] \quad 1.6 \% \quad 2.6 \%$

$0.03[0.00 ; 0.12] \quad 2.1 \% \quad 2.6 \%$

$0.02[0.00 ; 0.10] \quad 2.0 \% \quad 2.6 \%$

$0.00[0.00 ; 0.09] \quad 1.4 \% \quad 2.6 \%$

$0.00[0.00 ; 0.17] \quad 0.7 \% \quad 2.5 \%$

$0.35[0.30 ; 0.40] \quad 12.7 \% \quad 2.7 \%$

$0.21[0.15 ; 0.28] \quad 6.5 \% \quad 2.7 \%$

$0.30[0.23 ; 0.38] \quad 5.8 \% \quad 2.7 \%$

$0.08[0.04 ; 0.14] \quad 5.0 \% \quad 2.7 \%$

$0.29[0.18 ; 0.43] \quad 2.0 \% \quad 2.6 \%$

$0.33[0.22 ; 0.45] \quad 2.5 \% \quad 2.7 \%$

$0.25[0.09 ; 0.49] \quad 0.7 \% \quad 2.5 \%$

$0.44[0.34 ; 0.53] \quad 4.0 \% \quad 2.7 \%$

$0.48[0.46 ; 0.50] 100.0 \%$

$0.43[0.30 ; 0.57] \quad-\quad 100.0 \%$

Figure-12: Forest plot of studies on the prevalence of Porcine circovirus.

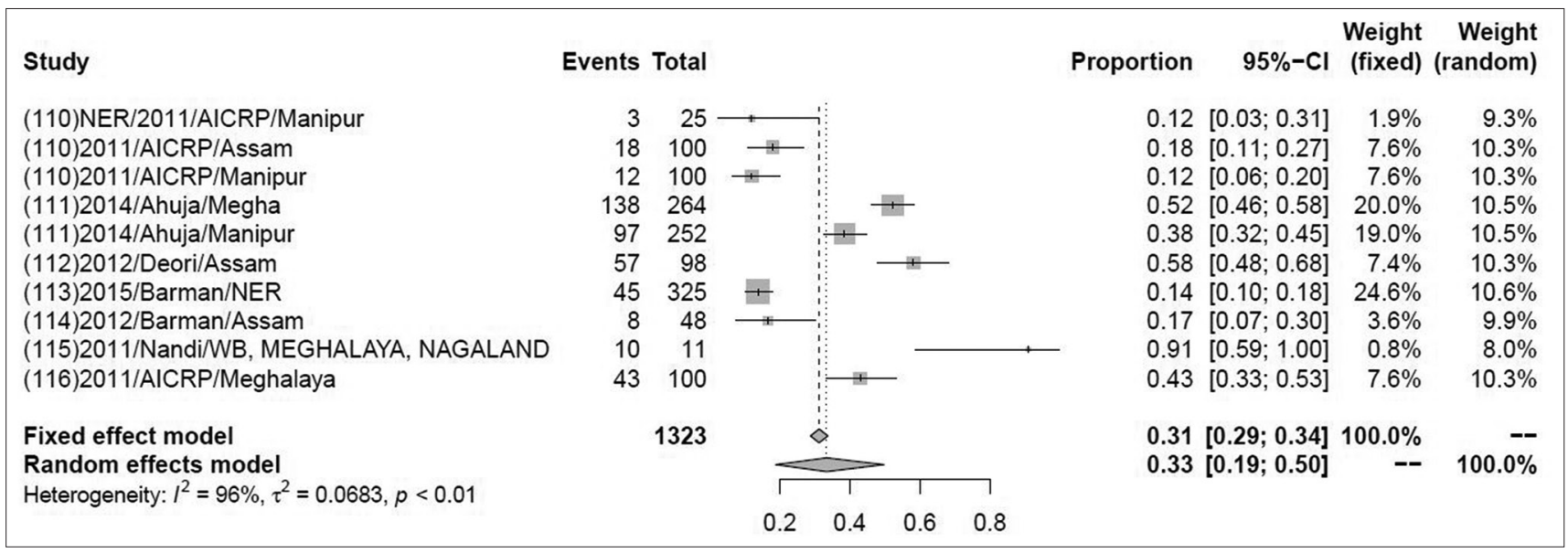

Figure-13: Forest plot of studies on the prevalence of classical swine fever.

prevalence of brucellosis was recorded, $1.45 \%$ in goat by RBPT, STAT, and I-ELISA [122]. The pooled prevalence of PCV in 2802 samples from 38 studies was found to be $43 \%$ ( $95 \%$ CI: $2-4 \%$ ), while a previous study suggested that the prevalence rate was higher in a total of 1899 serum samples collected and screened 


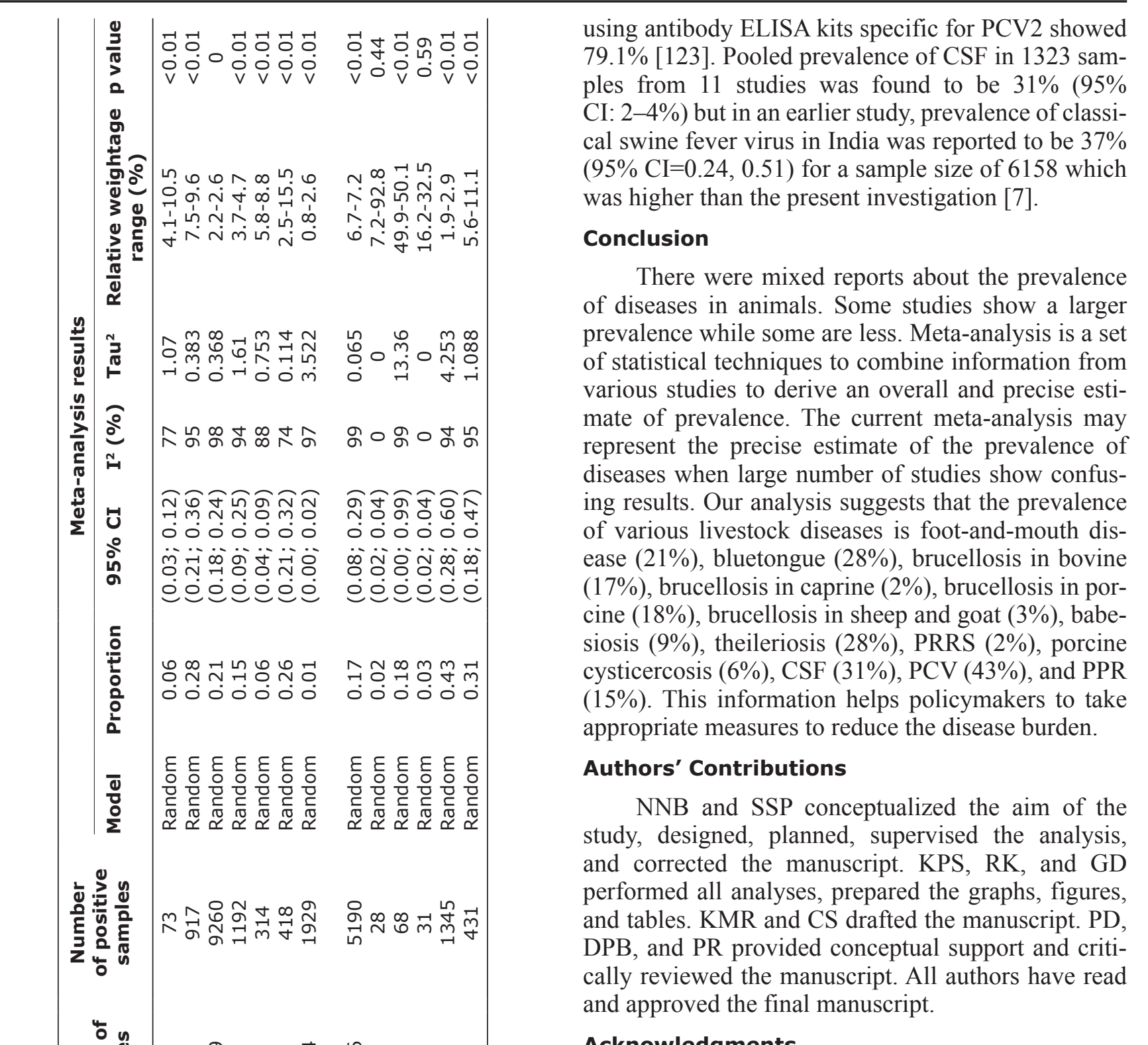

\section{Acknowledgments}

The authors gratefully acknowledge Department of Biotechnology- North Eastern Region-Advanced Animal Disease Diagnosis and Management Consortium program, India for funding and guiding this study under project code DBT-NER/ LIVS/11/2012-24-4-2014.

\section{Competing Interests} interests.

The authors declare that they have no competing

\section{Publisher's Note}

Veterinary World remains neutral with regard to jurisdictional claims in published institutional affiliation.

\section{References}

1. Livestock Census. (2012), Department of Animal Husbandry and Dairying, Ministry of Agriculture, Government of India, New Delhi.

2. National Accounts Statistics. (Various Years), Central Statistics Office, Government of India, New Delhi.

3. Kumar, A., Staal, S., Elumalai, K. and Singh, D.K. (2007) 
Livestock sector in North-Eastern Region of India: An appraisal of performance. Agric. Econ. Res. Rev., 20(3): 255-272.

4. Arendregt, J.J., Doi, S.A., Lee, Y.Y., Norman, R.E. and Vos, T. (2013) Meta-analysis of prevalence. J. Epidemiol. Community Health, 67(11): 974-978.

5. Haidich, A.B. (2010) Meta-analysis in medical research. Hippokratia, 14(Suppl 1): 29-37.

6. Asmare, K., Krontveit, R.I., Ayelet, G., Sibhat, B., Godfroid, J. and Skjerve, E. (2014) Meta-analysis of brucellosis seroprevalence in dairy cattle of Ethiopia. Trop. Anim. Health Prod., 46(8):1341-50.

7. Patil, S.S., Suresh, K.P., Saha, S., Prajapati, A., Hemadri, D. and Roy, P. (2018) Meta-analysis of classical swine fever prevalence in pigs in India: A 5-year study. Vet. World, 11(3): 297-303.

8. Choori, P., Patil, S.S., Rathnamma, D., Sharada, R., Chandranaik, B.M., Isloor, S., Geetha, S. and Rahman, H. (2014) Marker vaccines against classical swine fever a review. Indian J. Comp. Microbiol. Immunol. Infect. Dis., 35(1): 1-8.

9. Choori, P., Patil, S.S., Rathnamma, D., Sharada, R., Chandranaik, B.M., Isloor, S., Reddy, G.B., Geetha, S. and Rahman, H. (2015) Prevalence of classical swine fever in Karnataka, India. Vet. World, 8(4): 541-544.

10. Choori, P., Patil, S.S., Ratnamma, D., Prajapati, A., Mukartal, S.Y., Reddy, G.B., Suresh, K.P., Hemadri, D. and Rahman, H. (2017) Seroprevalence of classical swine fever in pigs of Karnataka and comparative diagnostic evaluation of antigen ELISA and reverse transcriptase-PCR. Ind. $J$. Anim. Sci., 87(12): 1457-1460.

11. Shivaraj, D.B., Patil, S.S., Ratnamma, D., Hemadri, D., Geetha, S., Narayanaswamy, H.D., Reddy, M., Sharada, R., Aralikatti, S.S. and Rahman, H. (2013) Early detection of classical swine fever virus in blood samples of pigs in Karnataka. Indian J. Comp. Microbiol. Immunol. Infect. Dis., 34(1): 18-23.

12. Shivaraj, D.B., Patil, S.S., Rathnamma, D., Sharada, R. and Desai, G.S. (2013) Molecular mechanisms involved in pathogenesis of classical swine fever. Indian J. Comp. Microbiol. Immunol. Infect. Dis., 34(2): 1-9.

13. Shivaraj, D.B., Patil, S.S. and Rathnamma, D. (2013) An insight into classical swine fever. Indian Farm., 63(2): 23-26.

14. Shivaraj, D.B., Patil, S.S., Rathnamma, D., Veeregowda, B.M., Hemadri, D., Geetha, S., Reddy, G.B.M., Sharada, R. and Rahman, H. (2013) Seroprevalence of classical swine fever in Karnataka. Indian J. Field Vet., 9(2): 26-27.

15. Shivaraj, D., Patil, S.S., Rathnamma, D., Hemadri, D., Isloor, S., Geetha, S., Reddy, G.B.M., Sharada, R. and Rahman, H. (2014) Phylogenetic analysis of recent classical swine fever isolates from Karnataka, India. Indian. J. Anim. Sci., 84(3): 236-239.

16. Shivaraj, D.B., Patil, S.S., Rathnamma, D., Hemadri, D., Isloor, S., Geetha, S., Reddy, G. B.M., Gajendragad, M.R. and Rahman, H. (2015) Genetic clustering of recent classical swine fever virus isolates from Karnataka, India revealed the emergence of subtype 2.2 replacing subtype 1.1. Virusdisease, 26(3): 170-179.

17. Patil, S.S., Suresh, K.P., Saha, S., Hamsapriya, S., Barman, N.N. and Roy, P. (2018) Import risk model: A quantitative risk assessment of classical swine fever virus (CSFV) introduction into Arunachal Pradesh via importation of pigs from neighboring countries. Indian J. Anim. Sci., 88(10): 11-13.

18. Patil, S.S., Suresh, K.P., Amachawadi, R.G., Meekins, D.A., Richt, D.A., Mondal, M., Hiremath, J., Hemadri, D. and Roy, P. (2019) Genome sequence of classical swine fever virus NIVEDI-165, subtype 1.1, a field virus strain isolated from the Southern part of India. Microbiol. Resour. Announc., 21(8): e00295-19.
19. Patil, S.S., Hemadri, D., Shankar, B.P., Raghavendra, A., Veeresh, H., Sindhoora, B., Chandan, S., Sreekala, K, Gajendragad, M.R. and Prabhudas, K. (2010) Genetic typing of recent classical swine fever isolates from India. Vet. Microbiol., 141(3-4): 367-373.

20. Patil, S.S., Hemadri, D., Veeresh, H., Sreekala, K., Gajendragad, M.R. and Prabhudas, K. (2012) Phylogenetic analysis of NS5B gene of classical swine fever virus isolates indicates plausible Chinese origin of Indian subgroup 2.2 viruses. Virus Genes, 44(1): 104-108.

21. Srinivasan, S., Easterling, L., Rimal, B., Niu, X.M., Conlan, A.J.K., Dudas, P. and Kapur, V. (2018) Prevalence of bovine tuberculosis in India: A systematic review and meta-analysis. Transbound. Emerg. Dis., 65(6): 1627-1640.

22. Scharnböck, B., Roch, F.F., Richter, V., Funke, C., Firth, C.L., Obritzhauser, W., Baumgartner, W., Käsbohrer, A. and Pinior, B. (2018) A meta-analysis of bovine viral diarrhea virus (BVDV) prevalences in the global cattle population. Sci. Rep., 8(1): 14420.

23. Borenstein, M., Hedges, L.V., Higgins, J.P.T. and Rothstein, H.R. (2009) Introduction to Meta-Analysis. John Wiley and Sons, Ltd., New York, USA. p77-85.

24. Singh, J., Miranpuri, G.S. and Borkakoty, M.R. (1978) Incidence of hemoprotozoan in bovines in NER of India. Int. J. Parasitol., 2(1): 137-138.

25. Chandra, D. and Rajkhowa, C. (1990) Compendium Incidence of Blood Protozoan Parasites in Cattle in Meghalaya, Proceedings of the $1^{\text {st }}$ Asian Congress of Veterinary Parasitology Held at Patna, Abs. No. S1. p49.

26. Mishra, A.K., Ravindran, R., Rao, J.K., Singh, N.G.I. and Udayakumar, M. (2002) Detection of Babesia bigemina in North Eastern Hill State of Manipur using PCR. Abstract Compendium of $13^{\text {th }}$ National Congress of Veterinary Parasitology. WBUAFS, Kolkata-S-IV-7.

27. Singh, I. and Devi, B.K.S. (2012-2013) Annual Report of Livestock Disease Profile of Manipur, Manipur Disease Investigation Laboratory, Directorate of Veterinary and Animal Husbandry Services, Manipur.

28. Singh, I. and Devi, B.K.S. (2014-2015) Annual Report of Livestock Disease Profile of Manipur, Manipur Disease Investigation Laboratory, Directorate of Veterinary and Animal Husbandry Services, Manipur.

29. Singh, I. and Devi, B.K.S. (2015-2016) Annual Report of Livestock Disease Profile of Manipur, Manipur Disease Investigation Laboratory, Directorate of Veterinary and Animal Husbandry Services, Manipur.

30. Singh, I. and Devi, B.K.S. (2016-2017) Annual Report of Livestock Disease Profile of Manipur, Manipur Disease Investigation Laboratory, Directorate of Veterinary and Animal Husbandry Services, Manipur.

31. Anon. (2013) Monthly Progress Report, North East Disease Diagnostic Laboratory, Assam.

32. Anon. (2014) Monthly Progress Report, North East Disease Diagnostic Laboratory, Assam.

33. Anon. (2015) Monthly Progress Report, North East Disease Diagnostic Laboratory, Assam.

34. Anon. (2016) Monthly Progress Report, North East Disease Diagnostic Laboratory, Assam.

35. Anon. (2015-2016) D.I.C. Department of Animal Husbandry \& Veterinary Services, Sikkim.

36. Anon. (2012-2013) Livestock Report, Manipur.

37. Anon. (2013-2014) Livestock Report, Manipur.

38. Anon. (2014-2015) Livestock Report, Manipur.

39. Anon. (2015-2016) Livestock Report, Manipur.

40. Anon. (2016-2017) Livestock Report, Manipur.

41. Lab Report. (2016-2017) Animal Resource Development Department (ARDD), Tripura and Department of Microbiology, West Bengal University of Veterinary Science and Fishery.

42. Joardar, S.N., Barkataki, B., Halder, A. and Lodh, C. (2013) Seroprevalence of bluetongue in North Eastern Indian state-Assam. Vet. World, 6(3): 196. 
43. Das, T.K. and Barman, N.N. (2015-2016) Serosurveillance, Isolation and Molecular Characterization of Blue Tongue Virus in Sheep and Goats of Tripura and Assam States. Department of Biotechnology (DBT), New Delhi.

44. Das, T.K. and Barman, N.N. (2016-2017) Serosurveillance, Isolation and Molecular Characterization of Blue Tongue Virus in Sheep and Goats of Tripura and Assam States. Department of Biotechnology (DBT), New Delhi.

45. Anon. (2008-2009) Annual Progress Report. All India Co-ordinated Research Project for Epidemiological Studies on Foot and Mouth Disease, ICAR-unit, Arunachal Pradesh.

46. Anon. (2009-2010) Annual Progress Report. All India Co-ordinated Research Project for Epidemiological Studies on Foot and Mouth Disease, ICAR-unit, Arunachal Pradesh.

47. Anon. (2010-2011) Annual Progress Report. All India Co-ordinated Research Project for Epidemiological Studies on Foot and Mouth Disease, ICAR-unit, Arunachal Pradesh.

48. Anon. (2011-2012) Annual Progress Report. All India Co-ordinated Research Project for Epidemiological Studies on Foot and Mouth Disease, ICAR-unit, Arunachal Pradesh.

49. Anon. (2012-2013) Annual Progress Report. All India Co-ordinated Research Project for Epidemiological Studies on Foot and Mouth Disease, ICAR-unit, Arunachal Pradesh.

50. Anon. (2013-2014) Annual Progress Report. All India Co-ordinated Research Project for Epidemiological Studies on Foot and Mouth Disease, ICAR-unit, Arunachal Pradesh.

51. Anon. (2014-2015) Annual Progress Report. All India Co-ordinated Research Project for Epidemiological Studies on Foot and Mouth Disease, ICAR-unit, Assam.

52. Anon. (2013-14) Annual Progress Report. D.I.C. Department of Animal Husbandry \& Veterinary Services, Sikkim.

53. Anon. (2010-2017) Annual Progress Report, North East Regional Disease Diagnostic Laboratory, Khanapara, Guwahati and Assam. Deputy Director AHC and I/C NERDDL, Assam.

54. Balamurugan, V., Das, S., Raju, D.S.N., Chakravarty, I., Nagalingam, M., Hemadri, D., Govindaraj, G., Singh, I.N., Ltu, K., Devi, M., Sharma, K., Gajendragad, M.R. and Rahman, H. (2014) Prevalence of peste des petits ruminants in goats in North-East India. Arunachal Pradesh. Virusdisease, 25(4): 488-492.

55. Devi, M., Das, S., Sharma, K. and Dutta, R. (2016) Seroprevalence and molecular detection of peste des petits ruminants in goats of Assam. VirusDisease, 27(1): 91-97.

56. Begum, S.S., Mahato, G., Sharma, P., Sharma, K., Hussain, M., Das, B.C., Hussain, J., De, A., Choudhary, D., Ramakrishnan, A.M. and Muthuchelvan, D. (2016) Seroprevalence of peste des petits ruminants in goats in Assam, India. Asian J. Anim. Vet. Adv., 11(3): 210-212.

57. Active Surveillance Data under ADMaC_ICAR-Barapani. (2015-2016) Meghalaya.

58. Islam, M. (2015) M. VSc Thesis, Prevalence, Pathology and Molecular Studies of Peste des Petits Ruminants in Goats of Assam.

59. Lab Report. (2016-2017) AH and Vety Department and Dairy Development, Arunachal Pradesh.

60. Active Surveillance Data under ADMaC_ICAR-Barapani. (2016) Meghalaya.

61. Active Surveillance Data under ADMaC_ICAR-Barapani. (2017) Meghalaya.

62. Raquib, A. (1966) A study on the incidence of Cysticercus cellulosae infection in pigs in Shillong area. J. Assam Sci. Soc., 8(1): 1-4.

63. Sharma, G.C. (1977) Studies of Human Taeniasis and Animal Cysticercosis in the Greater Guwahati Area of Assam, MVPH Thesis submitted to University of Calcutta, West Bengal.

64. Deka, D.K., Borkakoty, M.R. and Lahkar, B.C. (1985) Cysticercosis in domesticated animals in North Eastern region of India. Int. J. Parasitol., 9(1): 83-85.

65. Yadav, A.K. and Tandon, V. (1989) Helminths of public health significance in domestic animals of Meghalaya. Int J. Anim. Health, 28(2): 169-171.

66. Plain, B. (1991), Studies on the Incidence of Cysticercosis in Pig and Cattle with Special Reference to Taeniasis in Human Being in Assam, MVSc Thesis.

67. Devsarma, M.K. (1999) Some Aspects of Hydatidosis and Other Common Larval Cestodes of Domestic Animals. M.V.Sc. Thesis Submitted to Assam Agriculture University, Khanapara, Guwahati, Assam, India.

68. Anon. (2000-2001) ICAR Progress Report, Studies on Hydatidosis/Cystocercosis in Different Animals of NE Region, Assam. Department of Parasitology, CVSc, AAU, Khanapara, Assam, India.

69. Anon. (2001-2002) ICAR Progress Report, Studies on Hydatidosis/Cystocercosis in Different Animals of NE Region, Assam. Department of Parasitology, CVSc, AAU, Khanapara, Assam, India.

70. Borkotoki, S., Islam, S., Borkakoti, M.R., Goswami, P. and Deka, D.K. (2012) Prevalence of porcine cysticercosis in Nagaon, Morigaon and Karbi Anglong districts of Assam, India. Vet. World, 5(2): 86-92.

71. Kakoty, K. (2013) Prevelance of Porcine Cysticercosis and Human Taeniasis in Sivsagar District of Assam. M.V.Sc. Thesis Submitted to AAU, Khanapara, Guwahati, Assam, India.

72. Biswakarma, B. (2017) Epidemiology of Bladder Worm Diseases in Pig with Special Reference to Taenia solium Taeniasis in Man, M.VSc Thesis.

73. Active Surveillance Data under ADMaC_ICAR-Barapani. (2015) Meghalaya.

74. Das, S.S. and Sharma, N.N. (1994) Study of prevalence of Theileria sporozoites in the saliivary gland acinii of Hyalomma anatolicum anatolicum ticks in west district of Tripura (India). J. Parasit. Appl. Anim. Immunol. Biol., 2(1): 71-74.

75. Kakati, P. (2013) Studies on Ticks and Tick Borne Haemoparasitic Infection of Cattle in Assam, M.VSc Thesis Submitted to Assam Agriculture University, Assam.

76. Anon. (2013) Progress Report, North East Disease Diagnostic Laboratory, Assam.

77. Anon. (2014) Progress Report, North East Disease Diagnostic Laboratory, Assam.

78. Anon. (2015) Progress Report, North East Disease Diagnostic Laboratory, Assam.

79. Anon. (2016) Progress Report, North East Disease Diagnostic Laboratory, Assam.

80. Arif, S.A. (2017) Epidemiological Studies on Theileriosis in Goats of Assam, M.VSc Thesis Submitted to Assam Agriculture University, Assam.

81. Anon. (2012-2013) Lab Maintained Data, Tripura.

82. Anon. (2013-2017) Progress Report, North East Regional Disease Diagnostic Laboratory, Assam. Deputy Director AHC and I/C NERDDL, Guwahati, Assam.

83. Anon. (2012-2013) Progress Report of Livestock Disease Profile of Manipur, Manipur Disease Investigation Laboratory, Directorate of Vety and AH Services, Manipur.

84. Anon. (2014-2015) Annual Report of Livestock Disease Profile of Manipur, Manipur Disease Investigation Laboratory, Directorate of Vety and AH Services, Manipur.

85. Anon. (2016-2017) Annual Report of Livestock Disease Profile of Manipur, Manipur Disease Investigation Laboratory, Directorate of Vety and AH Services, Manipur.

86. Anon. (2013) Monthly Progress Report, State Disease Diagnostic Laboratory, Meghalaya.

87. Anon. (2014) Monthly Progress Report, State Disease Diagnostic Laboratory, Meghalaya.

88. Anon. (2015) Monthly Progress Report, State Disease Diagnostic Laboratory, Meghalaya.

89. Anon. (2016) Lab Report, Animal Resource Development Department, Tripura and ICAR-Barapani, Tripura.

90. Active Surveillance Data under ADMaC_ICAR-Barapani. (2017) Nagaland. 
91. Anon. (2013-2014) Lab Data, Animal Resource Development Department, ICAR-Barapani, Assam.

92. Anon. (2014-2015) Lab Data, Animal Resource Development Department, ICAR-Barapani, Assam.

93. Anon. (2015-2017) Lab Data, Animal Resource Development Department, ICAR-Barapani, Assam.

94. Anon. (2013-2015) Progress Report, North East Disease Diagnostic Laboratory, Assam, Dept of $\mathrm{AH}$ and Vety, Assam.

95. Chakravarty, A. and Barman, N.N. (2010) Detection of Brucella organism in urban herds of jersey crossbred cows in Assam (India) by bacteriological and antibody based tests. Anim. Sci. Rep., 4(4): 132-137.

96. Chakraborty, A., Barman, N.N. and Sarma, S. (2007) Seroprevalence of bovine brucellosis in different age groups of cattle. Indian Vet. J., 84(8): 873-874.

97. Anon. (2015-2016) Annual Report of Disease Investigation Laboratory, Department of A.H. and V.S. Sikkim.

98. Anon. (2013-2016) Combined Report of 3 Years, Department of A.H. and Vety, NERDDL, Khanapara.

99. Singh, I. and Devi, B.K.S. (2013-2014) Annual Report of Livestock Disease Profile of Manipur, Manipur Disease Investigation Laboratory, Directorate of Vety and $\mathrm{AH}$ Services, Manipur.

100. Mahato, G. (1999) Epidemiological Studies on Bovine Mastitis, Tuberculosis, Brucellosis and Foot and Mouth Disease in Organized Herds. Ph.D Thesis Submitted to Assam Agriculture University.

101. Saikia, G.K. (2015) Three Year Combined Progress Report on DBT Network Project on Brucellosis: SeroEpidemiology BE-3, Assam.

102. Chakraborty, M. (1998) Serosurveillance of Bovine and Caprine Brucellosis. M.V.Sc. thesis Submitted to West Bengal University of Animal and Fisheries Sciences, India.

103. Barman, N.N., Ahmed, K., Saikia, G.K. and Boro, B.R. (1989) Seroprevalence of brucellosis in organized cattle farms of Assam. Indian J. Anim. Health, 4(7): 99-102.

104. Gogoi, S.B., Hussain, P., Sarma, P.C., Barua, A.G., Mahato, G., Bora, D.P., Konch, P. and Gogoi, P. (2017) Prevalence of bovine brucellosis in Assam, India. J. Entomol. Zool. Stud., 5(4): 179-185.

105. Nath, A.J., Barman, N.N., Sarma, D.K., Das, S.K. and Bora, D.P. (2009) Seroprevalence of Brucella and parvovirus infection in pigs. Indian Vet. J., 86(4): 339-341.

106. Uttaran. (2015) Studies on Incident of Porcine circovirus and Porcine Parvovirus and Relation to Postweaning Multisystematic Syndrome in Meghalaya. Ph.D. Thesis Submitted, Assam University.

107. Anon. (2015) Progress Report, DBT NER Project on Advance Animal Disease Diagnosis and Management Consortium (ADMac), Aizwal, Mizoram.

108. Anon. (2011-2013) Progress Report, DBT Twinning Programme for A Study on Sero-Prevalence of Viruses Associated with Porcine Reproductive Problems, Assam.

109. Sharma, P. (2013) Studies on the Prevalence and Pathology of Reproductive in Sow in and around Guwahati. M.VSc Thesis Submitted to Assam Agriculture University, Khanapara.
110. Anon. (2011) Annual Progress Report. All India Co-ordinated Research Project for Epidemiological Studies on classical swine fever, ICAR-unit, Manipur.

111. Ahuja, A., Mukharjee, P., Bhattacharjee, U., Chakraborty, A.K., Karam, A., Ghatak, S., Puro, K., Das, S., Shakuntala, I., Srivastava, N. and Sen, A. (2014) Classicalswine fever virus infection in India: Seroprevalence study from north-eastern states of India. Indian J. Hill Farm., 27(2): 1-3.

112. Deori, L., Rahman, T. and Barman, N.N. (2012) Seroprevalance and pathology of classical swine fever (CSF) in pigs in certain districts of Assam. Indain. J. Vet. Pathol., 36(2): 143-147.

113. Barman, N.N., Gupt, R.S., Singh, N.K., Tiwari, A.K., Singh, R.K. and Das, S.K. (2015) Comparative evaluation of molecular and antibody based technique for detection of classical swine fever virus infecting pigs of north-east region, India. Indian J. Anim. Sci., 79(10): 974-977.

114. Barman, N.N., Sarma, D.K., Das, S.K. and Rahman, T. (2012) Final Progress Report on DBT Network Project on Classical Swine Fever with Special Reference to North Eastern Region and Subproject Entitled, Classical Swine Fever: Surveillance and Monitoring in Some North Eastern States and Establishment of National Classcial Swine Fever Virus Repository.

115. Nandi, S., Muthuchelvan, D., Ahuja, A., Bisht, S., Chanda, V., Pandey, A.B. and Singh, R.K. (2011) Prevalence of Classical Swine Fever Virus in India: A 6 Year Study. Transbound. Emerg. Dis., 58(5): 461-463.

116. Anon. (2014) Annual Progress Report. All India Co-ordinated Research Project for Epidemiological Studies on Classical Swine Fever, ICAR-unit, Assam.

117. Barman, U., Dutta, T.C., Baishya, B.C., Goswami, S., Islam, S., Phukan, A., Barman, D. and Kakati, P. (2018) Study of prevalence and diagnosis of babesiosis in cattle. J. Entomol. Zool. Stud., 6(3): 1613-1616.

118. Joardar, S.N., Halder, A., Lodh, C., Mahanti, A. and Barui, A. (2016) Seroprevalence of bluetongue in ruminants of Tripura. Indian J. Anim. Health, 55(2): 161-166.

119. Al-Ajeeli, K.S., Al-Azawy, A.K., AL-Anbagi, G.K. and Abdul-Rasoul, L.M.S. (2018) Sero-prevalence of foot-andmouth disease in cattle by $3 \mathrm{ABC}$ NSPELISA. Indian. $J$. Natural. Sci., 51(9): 15425-15678.

120. Borkataki, S., Islam, S., Borkakati, M.R., Goswami, P. and Deka, D.K. (2012) Prevalence of porcine cysticercosis in Assam, India. Vet. World, 5(2): 86-90.

121. Kumar, V., Kaur, P., Wadhawan, V.M., Pal, H., Sharma, H. and Kumar, P. (2015) Theileriosis in cattle: Prevalence and seasonal incidence in Jalandhar district of Punjab (India). Int. J. Recent Sci. Res., 6(3): 2998-2999.

122. Saikia, G.K., Konch, P., Boro, A., Shome, R., Rahman, H. and Das, S.K. (2019) Seroprevalence of caprine brucellosis in organised farms of Assam, India. J. Entomol. Zool. Stud., $7(1): 21-25$.

123. Gogoi, S.B., Hussain, P., Sarma, P.C., Gogoi, P. and Islam, M. (2017) Prevalence of brucellosis in goat in Assam, India. Int. J. Chem. Stud., 5(4): 1176-1179. 